\title{
After the harvest: investigating the role of food processing in past human societies
}

\author{
Aylen Capparelli • Soultana Maria Valamoti • \\ Michèle M. Wollstonecroft
}

Received: 25 February 2011 /Accepted: 8 March 2011 /Published online: 7 April 2011

(C) Springer-Verlag 2011

Plant processing provides an essential framework for archaeobotanical interpretation since practices of processing lie between the ancient acquisition of plants and the preserved remains of archaeology. Crop-processing stages have received much attention as they contribute towards the interpretation of plants recovered from archaeological sites, linking them to routine human activities that generated these plant remains. Yet, there are many other important aspects of the human past that can be explored through food processing studies that are much less often investigated, e.g. how culinary practices may have influenced resource selection, plant domestication and human diet, health, evolution and cultural identity. Therefore, this special issue of $A A S$ on "Food Processing Studies in Archaeobotany and Ethnobotany" brings together recent pioneering methodological and interpretive archaeobotanical approaches to the study of ancient food processing. This new research, which involves archaeobotany, ethnoarchaeology, ethnobotany and experimental methods, encompasses investigations into dietary choice,

\footnotetext{
A. Capparelli

Departamento Científico de Arqueología,

Museo de Ciencias Naturales de La Plata,

Paseo del Bosque $\mathrm{s} / \mathrm{n}^{\circ},(1900)$,

La Plata, Argentina

e-mail: aylencapparelli@fcnym.unlp.edu.ar

S. M. Valamoti

Department of Archaeology,

Aristotle University of Thessaloniki,

54 124, Thessaloniki, Greece

e-mail: sval@hist.auth.gr

M. M. Wollstonecroft $(\square)$

UCL Institute of Archaeology,

31-34 Gordon Square,

London WC1 0PY, UK

e-mail: m.wollstonecroft@ucl.ac.uk
}

cultural traditions and cultural change as well as studies of the functional properties (i.e. performance characteristics) of edible plants, and the visibility as well as dietary benefits and consequences of different food processing methods.

This volume builds on a history of experimental food processing in archaeobotany that dates back almost 40 years. Dennell $(1972,1976)$ was the first to model explicitly the importance of plant processing activities in shaping the archaeobotanical record. However, it was Hillman (see Willcox 2009; Hillman 1973, 1981, 1984) who, using an ethnoarchaeological approach, pioneered methods for linking the archaeobotanical record with the types of human plant-use activities that they potentially represent. As a result of his observations of the nonmechanised crop-processing techniques used by modern Turkish farmers, and his systematic sampling of the macrobotanical materials produced during each stage in the cropprocessing sequence, Hillman found that each stage produces a distinct plant assemblage that can be recognised from the specific types and condition of the plant parts represented. Building on Hillman's methods, Jones (1984, 1987) applied similar methods in Greece and instituted the use of quantitative methods to characterise the different plant macro-remain assemblages produced in each stage of the crop-processing sequence. More recently, Jones, along with Amy Bogaard, Mike Charles and their colleagues (e.g. see Jones 1992; Jones et al. 2005; Bogaard 2005; Charles et al. 2003) introduced functional ecology methods (FIBS) to further explore the types of information that the biological and ecological attributes of weeds found in archaeobotanical assemblages can provide about ancient crop-husbandry practices (crop sowing times, cultivation intensity and even ancient irrigation regimes). Such information is relevant to processing plants for food or other uses because crophusbandry practices inevitably affect the composition and condition of harvested batches of a crop as well as the 
character of the "clean" (threshed, raked, winnowed and sieved) grain (cf Hillman 1973).

Indeed, crop-processing studies have become an established component of archaeobotanical methodology, particularly among archaeobotanists studying the origins, evolution and spread of cereal agriculture in Europe, the Near East, North Africa and the Americas (e.g. Anderson et al. 2003; Anderson-Gerfaud 1991; D'Andrea 2003; D'Andrea and Haile 2002; Hastorf 1988, 1998; Johanessen et al. 1990; Butler et al. 1999; Peña-Chocarro 1999; Peña-Chocarro and Zapata Peña 2003; Peña-Chocarro et al. 2009; Stevens 2003; van der Veen 1992), similar methodologies have also been implemented in the Far East and South Asia, e.g. ethnographic research on millet crop processing in Nepal and India by Lundström-Baudais et al. (2002) and Reddy (1997), respectively, and Thompson's (1998) study of rice crop processing in Thailand. Moreover, not only plant macroremains but also, for the first time, micro-remains, such as phytoliths, have been used to investigate crop-processing in the work of Harvey and Fuller (2005).

Investigations into plant processing for the preparation of meals and/or specific food products, as well as applicable to other plant uses, with techniques such as pulverising, grinding, milling, boiling, roasting and baking, have more often been studied through processing equipment and resulting artefacts rather than the processed substance/mater resulting in the archaeobotanical remains incorporated in archaeological deposits (e.g. Andreoni 2010; Cueto et al. 2010; D'Andrea 2003; 10; Lyons and D'Andrea 2003; Peacock 2002; Procopiou and Treuil 2002a, b; Prevost-Demarkar 2002; Wright 1994, 2005). Procopiou and Treuil's (2002a, b) edited two-volume publication Moudre et Broyer I and II, for example, is a comprehensive collection of ethnographic and experimental studies on artefacts, tools and installations related to grinding and milling.

Archaeobotanical studies of plant processing for the preparation of specific foods, include those of Samuel (1997, $2000,2006)$ on bread and beer, Mangafa et al. $(1998,2001)$ on wine, Valamoti (2002) and Valamoti et al. (2008) on ground cereals, Capparelli (2008) on Andean legumes and Wollstonecroft (2007 and Wollstonecroft et al. 2008) on wild wetland tubers. These experimental studies involved ethnographic observations and the replication of plant processing methods, followed by the examination of the resulting foods under high power microscopy, and subsequent comparisons of their morphological and anatomical features with those of archaeological plant remains. Among the objectives of these studies are the creation of comparative materials to assist in the identification of archaeological food and fibre types, as well as learning about the types of equipment, materials, stages and labour involved in the preparation of various plant products, e.g. food, baskets, thread, etc. (Palmer 2002; Ertug 2000a, b, 2006). Additionally, these types of studies have provided a means for investigation connections between the plant-related activities and the social relationships of the group(s) under study, e.g. the rise of social hierarchies and gender issues (Hosoya 2009; Hastorf 1996, 1998).

Another important but less known branch of food processing research encompasses studies of the dietary aspects of ancient food processing (Hillman 2004 and in preparation; Samuel 1997, 2006; Wandsnider 1997; Wollstonecroft 2007; Wollstonecroft et al. 2008). Yen $(1980,1989)$ and later Stahl $(1984,1989)$ were among the first to consider the dietary and nutritional benefits of food processing as well its potential for increasing abundance and influencing human dietary selection and dietary change. Yen (1980) observed that processing provided people with a means of expanding the food uses of individual resources by permitting the production of a variety of foods from a single plant/plant part and/or preservation and storage. Stahl $(1984,1989)$ investigated the dietary advantages of food processing, observing that processing can facilitate the release of energy, nutrients and other important compounds (e.g. antioxidants) from foods (see also Johns 1999), as well as ensuring wholesomeness by improving palatability and destroying undesirable compounds. Given the universality of food processing among human societies, its likely time depth and the dietary implications, Stahl (1989) concluded that archaeologists should regard processing "....as an independent variable in our attempts to model the subsistence decisions made by prehistoric populations" (p 171).

Eight archaeobotanical/ethnobotanical/experimental studies on food processing are included in this volume. Six of these studies were first presented at the $\mathrm{V}$ International Congress of Ethnobotany (ICEB), in Bariloche, Argentina, September 2009, in a symposium organised by Capparelli, Valamoti and Wollstonecroft on "Recent research in postharvest traditions in human prehistory: Old and New World palaeoethnobotanical approaches to linking the archaeology and ethnobotany of plant processing", briefly summarised in the ICEB conference proceedings (Pochettino et al. 2010).

The papers presented here expand on the ICEB papers, providing detailed case studies on ancient food processing from three different continents (Asia, Europe and South America). Hosoya investigates ancient nut (e.g. chestnuts, pasanea nuts) processing and consumption through a combined use of archaeobotanical remains and ethnographic observations on modern nut processing in various parts of East Asia (Japan and China), highlighting the significance of such studies towards our understanding of the contribution of nuts to diets of past human populations; Valamoti describes and discusses archaeobotanical recognition and the economic and nutritional significance of 
specific ways of bulk processing of cereal grain for piecemeal consumption through a combined examination of archaeobotanical, ethnographic and textual evidence, as well as food science research, from Greece and circumMediterranean countries; and Stika investigates cereal malting and fermenting techniques used in the production of beers in Late Iron Age and early Medieval Germany. Borrowing a "post-harvest" approach from agronomy (see Wollstonecroft 2007; Capparelli and Lema 2010; Capparelli et al. 2010), Capparelli and Lema, Capparelli, Lema, Lopez et al. and Wollstonecroft investigate the functional links between the technological choices of ancient peoples and physiological properties of the plants that they processed; based on the data gathered from these investigations, these authors subsequently discuss the implied ecological and technological skills and knowledge of the ancient people under study. Capparelli and Lema, Capparelli and Lopez et al. explore the visibility of legume (Prosopis spp.) and pseudocereal (Chenopodium quinoa) processing in prehistoric Andean contexts of Northwest Argentina and Bolivia, and Lema analyses how processing and preservation practices may have influenced gourd (Cucurbita maxima) domestication. Wollstonecroft examines how innovations in food processing by Homo ancient ancestors may have influenced human evolution.

We are confident that the contributions of this special AAS issue will stimulate archaeologists to recognise that plant processing is a critical variable in human economies and social and symbolic systems; therefore it is essential to include it when modelling the life ways of past societies.

Acknowledgements We are indebted to the 5th ICEB organisers, Maria Lelia Pochettino and Anna Ladio (2010) for providing the initial opportunity for us to meet and discuss issues on ancient food processing in archaeobotany (ICEB conference Bariloche, Argentina, September 2009). Valamoti gratefully acknowledges the Aristotle University of Thessaloniki for providing funding for her participation in the conference and the AUTH Research Committee for financial support on her research on prehistoric processed cereals. Wollstonecroft's research and travel are supported by a British Academy Postdoctoral Fellowship and the UCL Institute of Archaeology. Great thanks to Dorian Fuller and the other editors of Anthropological and Archaeological Sciences for welcoming this special issue and to the anonymous reviewers for their constructive comments.

\section{References}

Anderson PC, L. Scott Cummings, TK Schippers and B Simonel (eds.). 2003. Le traitement des rrécoltes: Un regard sur la diversité, du Néolithique au présent. Actes des XXIIIe rencontres internationales d'archéologie et d'histoire d'Antibes. Antibes, Éditions APDCA

Anderson-Gerfaud PC (ed) (1991) Préhistoire de l'Agriculture. Nouvelles Approches Expérimentales et Ethnographiques. Centre de Recherches Archéologiques, Valbonne
Andreoni D (2010) Propuesta metodológica para reconocer las prácticas asociadas al uso de pipas arqueológicas Proceedings of the XVII National Congress of Argentinian Archaeology, Mendoza, 1211-1216

Bogaard A (2005) 'Garden agriculture' and the nature of early farming in Europe and the Near East. World Archaeol 37:177196

Butler A, Tesfay Z, D'Andrea C, Lyons D (1999) The ethnobotany of Lathyrus sativus L. in the highlands of Ethiopia. In: van der Veen $M$ (ed) The exploitation of plant resources in ancient Africa. Kluwer Academic/Plenum, New York, pp 123-136

Capparelli A (2008) Caracterización cuantitativa de productos intermedios y residuos derivados de alimentos del algarrobo (Prosopis flexuosa DC y P. chilensis (Mol.) Stuntz, fabaceae): aproximación experimental aplicada a restos arqueobotánicos desecados. Darwiniana 46(2):175-201

Capparelli A, V Lema (2010) Prácticas "post-aprovisionamiento" de recursos vegetales: una perspectiva paleoetnobotánica integradora aplicable al desarrollo de la arqueobotánica Argentina. Proceedings of the XVII National Congress of Argentinian Archaeology, Mendoza, pp 1171-1176

Capparelli A, Valamoti S, Wollstonecroft M (2010) Recent research in post-harvest traditions in human prehistory: Old and New World palaeoethnobotanical approaches to linking the archaeology and ethnobotany of plant processing. In: Pochettino ML, Ladio A, Arenas P (eds) Traditions and transformations in Ethnobotany, Cyted, S.S. de Jujuy. pp. 104

Charles M, Hoppe C, Bogaard A, Jones G, Hodgson JH (2003) Using weed functional attributes for the identification of irrigation regimes in Jordan. J Archaeol Sci 30:1429-1441

Cueto M, Capparelli A, Ciampagna L, Paunero M, Castro A (2010) Prácticas poscolecta y material leñoso: análisis de residuos y huellas microscópicas de origen vegetal, sobre artefactos de roca tallada utilizados en contextos experimentales. Proceedings of the XVII National Congress of Argentinian Archaeology, Mendoza, pp 1205-1210

D'Andrea AC (2003) Social and technological aspects of nonmechanised emmer processing. In: Anderson PC, Cummings LS, Schippess TS, and Simonel B (eds) The Traitement des Récoltes: Un Regard sur la diversité néolithique au présent. Éditions, Antibes, pp 47-60

D'Andrea AC, Haile M (2002) Traditional emmer processing in highland Ethiopia. J Ethnobiol 22:179-217

Dennell RW (1972) The interpretation of plant remains: Bulgaria. In: Higgs S (ed) Papers in economic prehistory. Cambridge University Press, Cambridge, pp 149-159

Dennell RW (1976) The economic importance of plant resources represented on archaeological sites. J Archaeol Sci 3:229247

Ertug F (2000a) Linseed oil mills in Central Turkey Flax/Linum and Eruca, important oil plants of Anatolia. Anatolian Stud 50:171185

Ertug F (2000b) An ethnobotanical study in Central Anatolia (Turkey). Econ Bot 54:155-182

Ertug F (2006) An overview of the plaited crafts of turkey (Anatolia and Thrace). In: Ertug $F$ (ed) Proceedings of the IVth International Congress of Ethnobotany (ICEB 2005), Yayinlari, Turkey, pp 297-306

Harvey E, Fuller DQ (2005) Investigating crop processing through phytolith analysis: the case of rice and millets. J Archaeol Sci 32:739-752

Hastorf C (1988) The use of paleoethnobotanical data in prehistoric studies of crop production, processing and consumption. In: Hastorf C, Popper V (eds) Current paleoethnobotany. Analytical methods and cultural interpretations of archaeological plant remains. University of Chicago Press, Chicago, pp 119-144 
Hastorf C (1996) Gender, space and food in prehistory. In: Preucel RW, Hodder I (eds) Contemporary archaeology in theory. Blackwell Press, Oxford, pp 460-484

Hastorf C (1998) The cultural implications of crop introductions in andean prehistory. In: Gosden C, Hather J (eds) The prehistory of food. Routledge, London

Hillman GC (1973) Crop husbandry and food production: modern models for the interpretation of plant remains. Anatolian Stud $23: 241-244$

Hillman GC (1981) Reconstructing crop husbandry practices from charred remains of crops. In: Mercer R (ed) Farming practice in British prehistory. Edinburgh University Press, Edinburgh, pp 123-162

Hillman GC (1984) Interpretation of archaeological plant remains: the application of ethnographic models from Turkey. In: Van Zeist W, Casparie W (eds) Plant and ancient man. studies in palaeoethnobotany. A. Balkema, Rotterdam, pp 1-41

Hillman GC (2004) The rise and fall of dietary diversity. Paper presented at the 2004 meeting of the Society of Economic Botany, Canterbury

Hillman GC In Prep. Foraging and processing wild roots, seeds, berries and greens: foods of our hunter-gatherer forbearers

Hosoya L (2009) Sacred commonness: an archaeobotanical approach to Yayoi social stratification: the 'Central Building Model' and the Osaka Ikegami Sone Site. Interactions between huntergatherers and farmers: from prehistory to present. In: Ikeya K, Ogawa H, Mitchell P (eds) Senri ethnolgical studies 73. National Museum of Ethnology, Osaka, pp 99-178

Johanessen S, Goette S, Hastorf C (1990) Modern and ancient maize fragments: an experiment in variability. J Quant Anthropol 2:179-200

Johns T (1999) The chemical ecology of human ingestive behaviours. Annu Rev Anthropol 28:27-50

Jones G (1984) Interpretation of archaeological plant remains: ethnographic models from Greece. In: Van Zeist W, Casparie $\mathrm{W}$ (eds) Plants and ancient man. A Balkema, Rotterdam, pp 43-61

Jones G (1987) A statistical approach to the archaeological identification of crop processing. J Archaeol Sci 14:311-323

Jones G (1992) Weed phytosociology and crop husbandry: identifying a contrast between ancient and modern practice. Rev Palaeobot Palynol 73:133-43

Jones G, Charles M, Bogaard A (2005) The functional ecology of present-day arable weed floras and its applicability for the identification of past crop husbandry. Veg Hist And Archaeobotany 14:493-504

Lundström-Baudais KA, Rachoud-Schneider M., Baudais D, Poissonnier B (2002) Le broyage dans la chaîne de transformation du millet (Panicum miliaceum): outils, gestes et écofacts. In: Procopiou H and Treuil R (eds) Moudre et Broyer: I. Méthodes. Comité des Travaux Historiques et Scientifiques, Paris, pp 155-180

Lyons D, D'Andrea AC (2003) Griddles, ovens, and agricultural origins: an ethnoarchaeological study of bread baking in Highland Ethiopia. Am Anthropol 105:515-530

Mangafa M, Kotsakis K, Andreou S (1998) A $\mu \pi \varepsilon \lambda_{0 K} \alpha \lambda_{\iota} \varepsilon \dot{\varepsilon} \rho \varepsilon \varepsilon\llcorner\alpha$

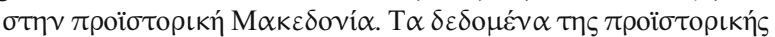
Tov́ $\mu \pi \alpha \varsigma \Theta \varepsilon \sigma \sigma \alpha \lambda o v i ́ k \eta \varsigma$ (Viticulture in prehistoric Macedonia; the archaeobotanical evidence from Toumba Thessalonikis). In History of the Grape Vine and Viticulture in Macedonia and Thrace: 158-169. Athens, ETBA publications

Mangafa M, Kotsakis K, Stratis I (2001). П $\varepsilon\llcorner\rho \alpha \mu \alpha \tau \iota k \eta ́$

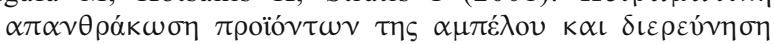

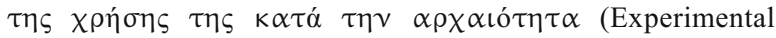
charring of grape vine products and an investigation of their use in antiquity). In Bassiakos Y, Aloupi E, Fakorellis G (eds)

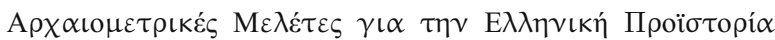
$\kappa \alpha \iota \mathrm{A} \rho \chi \alpha \iota \operatorname{có}_{\tau \eta} \tau \alpha$ (Archaeometric Studies in Greek Prehistory and Antiquity). Athens, Greek Society of Archaeometry and Society of Messinian and Archaeological Studies

Palmer C (2002) Milk and cereals: identifying food and food identity among Fallahin and Bedouin in Jordan. Levant 34:173-195

Peacock S (2002) Perusing the pits: the evidence for prehistoric root resource processing on the Canadian Plateau. In: Mason SLR, Hather JG (eds) Hunter-gatherer archaeobotany: perspectives from the Northern Temperate Zone. UCL Institute of Archaeology, London, pp 44-61

Peña-Chocarro L, Zapata Peña L, González Urquijo JE, Ibáñez Estévez JJ (2009) Einkorn (Triticum monococcum L.) cultivation in mountain communities of the western Rif (Morocco): an ethnoarchaeological project. In: Fairbairn A, Weiss E (eds) Ethnobotanist of distant pasts: archaeological and ethnobotanical studies in honour of Gordon Hillman. Oxbow, Oxford

Peña-Chocarro L (1999) Prehistoric agriculture in Spain. The application of ethnographic models, Oxford, British Archaeological Reports, 1999 (British Archaeological Reports International Series 818)

Peña-Chocarro L, Zapata Peña L (2003). Post-harvesting processing of hulled wheats. An ethnoarchaeological approach. In: Anderson PC, Scott Cummings L, Schippers T and Simonel B (eds) Le traitement des récoltes: Un regard sur la diversité, du Néolithique au présent. Actes des XXIIIe rencontres internationales d'archéologie et d'histoire d'Antibes. Éditions APDCA, Antibes, pp 99-113.

Pochettino ML, Ladio A, Arenas P (eds) (2010) Traditions and transformations in Ethnobotany. In: Proceedings of the $\mathrm{V}$ International Congress of Ethnobotany, ICEB 2009. Cyted, S.S. de Jujuy

Prevost-Demarkar S (2002) Les foyers et les fours domestiques en Egee au Neolithique et a l'Age du Bronze. Civilisations 49:223-237

Procopiou H, Treuil R (eds) (2002a) Moudre et Broyer, Volume I. Méthodes, Paris, CTHS

Procopiou H, Treuil R (eds) (2002b) Moudre et Broyer, Volume II. Archéologie ethistoire, Paris, CTHS

Reddy SN (1997) If the threshing floor could talk: integration of agriculture and pastoralism during the Late Harappan in Gujarat. India J Anthropol Archaeol 16:162-187

Samuel D (1997) Cereal food and nutrition in ancient Egypt. Nutrition 13:579-580

Samuel D (2000) Brewing and baking. In: Nicholson PT, Shaw I (eds) Ancient Egyptian materials and technology. Cambridge University Press, Cambridge, pp 537-576

Samuel D (2006) Modified starch. In: Torrence R, Barton H (eds) Ancient starch research. Left Coast Press, Walnut Creek, pp 205-216

Stahl AB (1984) Hominid dietary selection before fire. Curr Anthropol 25:151-168

Stahl AB (1989) Plant-food processing: implications for dietary quality. In: Harris DR, Hillman GC (eds) Foraging and farming: the evolution of plant exploitation. Unwin Hyman, London, pp 171-196

Stevens CJ (2003) An investigation of agricultural consumption and production models for prehistoric and Roman Britain. Environ Archaeol 8:61-76

Thompson J (1998) Subsistence and environment: the botanical evidence. The biological remains (part II), volume IV of the excavation of Khok Phanom Di, a prehistoric site in Central Thailand. The Society of Antiquaries, London

Valamoti SM (2002) Food remains from Bronze Age Archondiko and Mesimeriani Toumba in northern Greece? Veg Hist Archaeobot $11: 17-22$

Valamoti SM, Samuel D, Bayram M, Marinova E (2008) Prehistoric cereal foods from Greece and Bulgaria: investiga- 
tion of starch microstructure in experimental and archaeological charred remains. Veg Hist Archaeobot 17(suppl 1):265276

van der Veen M (1992) Crop husbandry regimes (Sheffield Archaeological Monographs 8). J. R. Collis Publications, Sheffield

Wandsnider L (1997) The roasted and the boiled: food composition and heat treatment with special emphasis on pit-hearth cooking. J Anthropol Archaeol 16:1-48

Willcox G (2009) Gordon Hillman's pioneering influence on Near Eastern archaeobotany, a personal appraisal. In: Fairbairn A, Weiss E (eds) From foragers to farmers. Oxbow, Exeter, pp 15-18

Wollstonecroft M (2007) Post-harvest intensification in late pleistocene Southwest Asia: plant food processing as a critical variable in epipalaeolithic subsistenceand subsistence change. Unpublished $\mathrm{PhD}$ thesis, UCL Institute of Archaeology, London
Wollstonecroft M, Ellis PR, Hillman GC, Fuller DQ (2008) Advancements in plant food processing in the Near Eastern Epipalaeolithic and implications for improved edibility and nutrient bioaccessibility: an experimental assessment of sea club-rush (Bolboschoenus maritimus (L.) Palla). Veg Hist Archaeobotany 17(suppl 1):S19-S27

Wright K (1994) Groundstone tools and hunter-gatherer subsistence in Southwest Asia: implications for transition to farming. Am Antiquity 59:238-263

Wright K (2005) The emergence of cooking in western Asia. Archaeol Int 2004-2005:33-37

Yen DE (1980) Food crops. In: Ward RB, Proctor A (eds) South pacific agriculture: choices and constraints. Agricultural Development Bank, Manila

Yen DE (1989) The domestication of environment. In: Harris DR, Hillman GC (eds) Foraging and farming: the evolution of plant exploitation. Unwin Hyman, London, pp 55-75 